Cost of dusting per tree

Amount of dust per tree

Amount of spray per tree

Net returns from one spraying per tree

" " " " " " " " "usting " " $"$ " acre

Net difference per acre in favor of spray
Orchard $A$

.75

$10 \mathrm{lbs}$

33 gals.

$\$ 1.22$

.46

18.30

6.90

11.40
Orchard $D$

.44

6 lbs.

20 gals.

$\$ 2.30$

1.28

46.00

25.60

20.40

\title{
TWO INJURIOUS FRUIT MITES IN PENNSYLVANIA
}

By S. W. Frost, Ent. Research Laboratory, State College, Pa.

Two mites have been found injurious on fruit trees in Pennsylvania. One is the European Plum Mite, Paratetranychus pilosus Can. \& Fran., which was previously recorded in the JourNaL ${ }^{1}$ as a pest chiefly on apple and plum although it occurred to some extent on cherry and peach. A second mite, Phyllocoptes cornutus Banks has recently been found very abundant in parts of the state on peach. This species was first noticed in Cumberland county, Pennsylvania, in 1921, by Mr. W. A. McCubbin, Deputy Director State Bureau of Plant Industry, Harrisburg, and was thought at first to be a silver leaf resembling closely the European silver-leaf disease. Further examination and a consultation with an entomologist has identified the injury with that of a small mite which Mr. Nathan Banks has previously described and recorded from this country. It has also been found in Lebanon, Dauphin, and Adams counties and further examination will no doubt reveal its presence in other parts of the state.

Both species produce characteristic injury upon their hosts. The European Plum Mite causes the leaves to turn yellowish and later become bronzy in color. The silver Leaf-mite of peach causes the leaves to become silvery and later become leaden in color. Both species have a tendency to flatten the leaves so that the appearance from a distance is very different from the normal foliage.

\section{Scientific Notes}

Aroostook Potato Insects ${ }^{2}$. Since aphids have been found to transfer potato mosaic and leaf roll (Bulletins 292, 297, and $303 \mathrm{Me}$. Agr. Exp. Sta.), and certain other insects with piercing and sucking mouthparts are being viewed with suspicion,

1Journ. Econ. Entomology, Vol. 12, pp. 407-408, 1919.

'Papers from the Maine Agricultural Experiment Station: Entomology No. 111. 